\title{
International business and management: roads behind, roads ahead
}

\author{
Gerhard Apfelthaler • Vlad Vaiman
}

Published online: 6 February 2013

(C) International Network of Business and Management 2013

\begin{abstract}
This paper briefly describes a complex, multi-level, and multidisciplinary environment of international business and management and shows the important role of European Journal of International Management in advancing the field.
\end{abstract}

Keywords International management - International business - Critique · Research · Academic journals

We may argue if we live in a completely globalized or "semi-globalized" (Ghemawat 2003) world of business, but there are two undeniable facts: first, the world has experienced a dramatic increase in the transnational flow of goods, services, and capital over the last fifty years. Between 1950 and 2000, world trade has increased 16-fold, and international trade flows relative to gross domestic product have doubled between 1970 and 2000 (OECD 2005). Second, the interest of management educators and scholars in issues related to the internationalization of business has steadily increased. Curricula have been reformed to incorporate topics relevant to internationalization, entire programs have developed around the subject, textbooks have been written and related research has been given its own arenas in the form of specialized journals such as the Journal of International Business Studies, the Journal of World Business, the Journal of International Marketing,

\section{G. Apfelthaler}

School of Management, California Lutheran University, 60 West Olsen Road \#3550,

Thousand Oaks, CA 91360, USA

e-mail: apfeltha@callutheran.edu

V. Vaiman $(\varangle)$

School of Business, Reykjavik University, Menntavegur 1, Reykjavik 101, Iceland e-mail:vlad@ru.is 
International Business Management, the International Marketing Review, the Journal of International Management, the International Business Review, the European Journal of International Management, or the International Journal of Intercultural Relations, associations such as the Academy of International Business, the European International Business Academy, or the International Management Division of the Academy of Management, and conferences such as the Annual Meeting of the Association of International Business or the various activities of the International Management Division within the annual Academy of Management conference, to name but a few.

International business as an academic discipline is a complex field. It deals with the internationalization process itself, with specifics of various functional areas of management in international settings, with variations in institutional settings and differences in cultural environments, and-ultimately-the nature of firms. In the early 1950s and 1960s, little attention was still given to international issues by academic management journals. Interest in the field developed after the formation of special interest groups such as the Association for Education in International Business in 1958 (Behrman 2006) and early inquiries into foreign direct investment by authors such as Penrose (1956), Fayerweather (1960), Hymer (1960), Aharoni (1966), Vernon (1966), Hirsch (1967), Keegan (1967), or Kindleberger (1969). The 1970s brought both a diversification in perspectives on international business and the establishment of international business as a discipline. Over time, attention turned to the phenomenon of the multinational firm (e.g., Wilkins 1970; Wilkins 1974; Buckley and Casson 1976; Dunning 1977) and the internationalization process with new theories of internationalization emerging, such as the stage theory of internationalization that is often also referred to as the Uppsala model (e.g., Johanson and Wiedersheim-Paul 1975; Johanson and Vahlne 1977). Particularly, in the decades of the 1980s and 1990s with their high activity levels in international trade, international business was "catapulted into the realm of the current and the relevant" (Shenkar 2004). Work on exports (e.g., Leonidou and Katsikeas 1996), export performance (e.g., Cavusgil and Zou 1994; Zou et al. 1998), and export promotion (e.g., Czinkota 1994; Durmusoglu et al. 2012) were published.

New paradigms (Sullivan and Daniels 2005) and perspectives started to emerge, including transaction cost economics (Anderson and Gatignon 1986; Hennart 1991), and the host of literature around what is often referred to as "born-globals" (e.g., Rennie 1993; Knight and Cavusgil 1996; Madsen and Servais 1997; Moen 2002; Moenand Servais 2002; Knight and Cavusgil 2005), "international entrepreneurs" (McDougall 1989), "global start-ups" (Oviatt and McDougall 1995), "international new ventures" (Oviattand McDougall 1994; Zahra et al. 2000), as well as the related literature on network theory in international expansion (Chetty and Blankenburg Holm 2000; Oviatt and McDougall 2005). More recently, along with a heightened interest in emerging economies, there has been a growing recognition of the fact that differences in the home and host country's formal and informal institutional environment exert significant influence over firms, resulting in institutional theory of international business (e.g., Leung et al. 2005; Peng et al. 2008; Kostova et al. 2008). In parallel, a growing interest in the process of management across borders started to develop (e.g., Bartlett and Ghoshal 1989), particularly with respects to the 
role of culture (e.g., Hofstede 1980) and issues of international human resource management.

Despite an incredible number and breadth of articles published in several journals dedicated to the field, ${ }^{1}$ some authors criticize an observable lack of relevance (Oesterle and Laudien 2007) and raise the question if the international business research agenda is "running out of steam after a period of vibrancy" (Buckley 2002). But, what do we even mean when we talk about international business?

Defining international business (IB) and international management (IM) is both easy and complex at the same time. It is easy as both fields deal with bordercrossing activities of individuals and organizations. International business focuses on the organization, the "international-multinational-transnational-global-businessenterprise-firm-company-corporation" (Peng 2004) as a unit of analysis as it aims to understand "the business enterprise and its activities across nation-state borders" (Eden et al. 2010-11). International management, on the other hand, deals with the individual as it refers to the "process of applying management concepts and techniques in a multinational environment" (Luthans and Doh 2009), or, in greater detail, to the process of planning, organizing, directing, and controlling the organization, which individuals use to achieve an organization's goals when the organization is involved in cross-border activities or functions outside its nationstate" (Eden et al. 2010-11). IM, in a certain sense, is therefore a subset of IB. In addition, more recently, yet another distinct area of inquiry seems to be emerginginternational strategy (IS), itself a subset of IM (Eden et al. 2010-11) and closely related to strategic management research (e.g., Peng 2001; Shenkar 2004; CuervoCazurra et al. 2007).

When it comes to education and research, the lines between IB, IM (and IS) are often blurry. Scholarly journals as well as academic associations in the wider field clearly overlap with each other. What they do share, however, is a certain eclectic nature, all pursuing a plethora of phenomena, theoretical and methodological perspectives. This has led to a state of research in the field that clearly has some outstanding issues and has brought it to certain crossroads (Shenkar 2004). Some authors even speak of IB/IM coming "under attack" (Shenkar 2004) and the lack of a "big question" in IB/IM research (Buckley 2002).

As growing fields, IB and IM encounter a number of limitations that tend to impede their progress. These limitations relate mainly to some existing approaches of conducting research in IM. Among such approaches are nearly exclusive reliance on quantitative methods, obtaining information from a single discipline, doing research that is theory-motivated and phenomenon-based (Cheng 2007), as well as predominance of the North American context in most formative works in the area.

Looking at the majority of recent publications in the field, it is not difficult to notice an overwhelming prevalence of quantitative over qualitative research. While the quantitative approach is undoubtedly useful-for instance, in the analysis of industry characteristics - and powerful_although almost exclusively for large effect sizes (Brock 2003) — it clearly fails to capture the richness of the field (Doz 2011). Phenomena that are difficult to measure, such as behavioral variables,

\footnotetext{
$\overline{1}$ For an analysis of articles and an identification of themes over a 10 year period, see Griffith et al. 2008.
} 
national cultures, and other contextual factors are thereby neglected. In addition, qualitative research is always a challenging undertaking, which is also not very much welcomed by mainstream IM academic journals. So, incentives to conduct high-quality, rigorous qualitative research that helps to open the black box of IB/IM and contribute to theory development (Doz 2011) are really scant.

The second approach limiting the progress of IM research is the preference of most scholars to draw knowledge from a single discipline, such as sociology, psychology, political science, or economics (which is often considered the parent discipline of IB). Despite the complex nature of the environment of international business, the borders are less permeable than some authors portray them (e.g., Peng 2004) and research outcomes, therefore, often remain disconnected, dispersed and in need of an integrative framework (Cheng 2007) that piece together what Dunning (2002) has called the "rich mosaic of inter-related disciplines." To make things worse, even within the field of international management itself, scholars prefermostly for publishing reasons - to analyze issues in the frameworks of a single subject such as marketing, human resource management, or leadership. This "silo" approach not only impedes the progress of IM research but also damages it for the lack of cross-fertilization between IB/IM and functional disciplines (Aggarwal et al. 2008).

The third issue is the approach of conducting IM research that is theorymotivated and phenomenon-based, as opposed to being phenomenon-motivated and theory-based. In other words, more and more IM studies aim to probe and expand existing theories from other and perhaps more established social science disciplines (Cheng 2007), instead of attempting to develop new theories to explain the phenomenon in question. Sometimes it seems as though the theories are being extended simply for the sake of extending theories without even trying to connect them to a real managerial problem. Cheng (2007 p. 26) suggests that instead of asking questions like "What does transaction cost theory have to say about joint venture governance and how can research on this topic help further advance transaction theory?" or "Are theories of organization and management developed in the West, e.g., institutional theory and resource-based view of the firm, valid in Asian societies?"; IM researchers should ask "Why do multinational firms exist and what determines their effective functioning?"; or "Why are there cross-national differences in management practice and what accounts for these differences?" This latter approach does certainly make much more sense.

Another issue is, ironically, the ethnocentric nature of existing IB/IM/IS research. Contributions in mainstream IB/IM journals are predominantly written by North American authors (Shenkar 2004), focusing on North-American companies or on phenomena within a single context (Eden et al. 2010-11), effectively neglecting the new reality of rapidly emerging economies around the globe (Fruin 2007). So, in a way, it is necessary to bring back the "international" to international business, management, and strategy.

In order to address these and other challenges mentioned below, in 2007 a group of scholars from around the world has set on establishing a new academic outlet, European Journal of International Management (EJIM). EJIM has, therefore, become the first international journal dedicated entirely to fostering an 
understanding of issues in international business and management theory and practice in the larger European arena-including the underrepresented regions of Northern, Central, and Eastern Europe-and to providing both conceptual and functional implications useful for the further development of research, teaching practices, and managerial techniques.

One of the strongest points distinguishing EJIM from similar academic publications is that the journal solicits literature allowing for a broader interpretation of research-it welcomes not only papers which adhere to the most common research standards (i.e., largely based on hypotheses testing using quantitative methods) but also those that introduce what some may consider a more European perspective of conceptual, qualitative, and interdisciplinary contributions. The main objective of EJIM is to sustain an outlet for scholars interested in a variety of topics in international business and management, including but not limited to those specific to the European environment, international strategy, international HRM, cross-cultural management, leadership, and entrepreneurship. EJIM's publications are aimed not only at the academic community preoccupied with purely conceptual research but also at other academics actively involved in transferring theoretic wisdom into actionable knowledge.

To fully understand what EJIM stands for, it may be useful to provide a brief compilation of contributions that reflect the breadth and the tone of the journal that give it a distinctive voice among other leading journals in the field of international business and management. For instance, in his seminal paper, "A new Zeitgeist for international business activity and scholarship," the late John Dunning (2007) suggests that IB scholarship is at a turning point in its advancement. The paper first sets out the reasons for this assertion and then proceeds to identify the key changes in the physical and human environment that are influencing the global pursuits of Multinational Enterprises (MNEs). The paper concludes by suggesting that IB scholars need to modify and adjust their research methodologies, if they want to truly understand and explain the increasingly important role of institutions in determining the strategies of MNEs and the impact of these institutions on the countries' competitiveness.

The paper "Cultural values in organizations: insights for Europe" by Lilach Sagiv and Shalom Schwartz (2007) examines how the values of the society in which an organization is embedded affect the values of the organization. Sagiv and Schwartz discuss three major sources of influence: the value culture in the society, personal value priorities of organizational members, and the nature of the organization's main tasks. The authors suggest that the societal culture affects organizational values both directly and indirectly through its influence on members' values and the nature of organizational tasks.

The 2007 paper by Chris Brewster named "A European perspective on HRM," just as the title suggests, provides a European perspective on Human Resource Management (HRM). The paper explores this issue by scrutinizing the growing field of comparative HRM, looking into some of the conceptual approaches to the topic and the different explanations for national differences that they advocate, and considering some of the issues that make HRM in Europe unique. The paper also examines the notion of Europe itself and the differences within it, and considers 
whether the variations within the continent are diminishing over time as a result of globalization. The author ultimately argues that Europe offers a wider ranging and more critical concept of HRM (Brewster 2007).

"Practical wisdom and the development of cross-cultural knowledge management: a global leadership perspective" is the title of 2010 paper by David Pauleen, David Rooney, and Nigel Holden. In this paper, the authors respond to calls for more pragmatic and context-dependent cross-cultural scholarship. More specifically, with regard to global companies, the authors attempt to "reconcile the imbalance between global and local concerns by proposing a framework that merges a new understanding of culture with a classical leadership approach" (p. 382) with the main objective of achieving more successful cross-cultural practice. The paper makes the case for a better awareness of what is referred to as "cross-cultural knowledge management" and the role of knowledge in global business leadership in a contemporary culturally diverse economy (Pauleen et al. 2010).

The paper "Case selection biases in management research: the implications for international business studies" by Simon Collinson and Alan Rugman (2010) reports on a bibliometric analysis of peer-reviewed articles in business and management conducted between 2004 and 2009 and reveals that a rather small number of companies account for over a half of the total "hit count" for all firms in the authors' list of the largest 200 MNEs. One of the most important implications of this finding is that the scholars seem to obtain most of their academic insights and so-called "best-practices" in management from quite a small and unrepresentative group of "model companies." The authors have also been able to identify seven case selection biases, illustrating a disproportionate focus on a subset of companies that are: global and bi-regional, US-based, large, manufacturers, in dominant positions in important industries, long-term survivors, and owners of strong brands. The paper then goes on to examining the first of these biases more closely and concludes with the assertion that a large number of business and management studies tend to overestimate the benefits and underestimate the difficulties of internationalization.

As one can see, these exemplary contributions attempt to address some of the main challenges described above, and by so doing provide the readers with a clear understanding of EJIM's main purpose and objectives. There were obviously other major reasons for pursuing the establishment of this journal, such as providing the viable alternative to a somewhat parochial and ethnocentric view on international management, as well as attempting to bridge that proverbial gap between theory and practice by providing insights into the complex problems that businesses face around the world. The latter issue has been on the radars of EJIM editorial board from the very beginning, as it is deeply connected with the challenges of IM scholarship described above. EJIM board team members believe that the journal's role in attempting to bridge the gap between theory and practice can be fulfilled first and foremost by directing the contributors to provide a basic framework for understanding managerial problems, rather than try to achieve immediate relevance. In addition, potential contributors should keep in mind that to offer insight into the problems businesses face nowadays, it is necessary to cross disciplines, because the problems themselves are interdisciplinary in nature. 
However, being able to look at the problem at hand through an interdisciplinary lens is a major task by itself. Why? Simply because, in most business schools, that the authors are intimately familiar with, both research and teaching curricula are built within professional silos and are designed for individual academics to further their careers and not to tackle the problems of business. In addition, the social and behavioral sciences in general have not done a good job of focusing on practice. Business schools do not really keep track of the advances in practice; they keep track of what is going on in their narrow disciplines and what is being published in various relevant journals. That is mostly because the system rewards individual professors who achieved something within their silos, as opposed to interdisciplinary achievements. While it is really difficult (if not impossible, at least in the short run) to change the system, EJIM is trying its best to shake system's canons by inviting the submission of papers that are based on a solid inter- and multidisciplinary research.

By and large, EJIM is designed to serve a slightly wider segment of the academic audience by offering strong implications for research, teaching, and practicing communities, while still maintaining both academic quality and rigor. It does not claim to level the path to the "big question" in IB, it rather embraces the ideas of exploration, diversity, and novelty. EJIM publishes original papers, case studies, book reviews, commentaries, and conference notes. Special issues dedicated to important topics in European international management are published on the regular basis. Despite its European orientation, EJIM welcomes authors from all over the world, including North America, Asia, and South-Pacific.

EJIM also publishes a regular section that includes a synopsis of important findings from articles appearing in any relevant non-English journals in Europe, Asia, South America, etc. The benefits of this feature are threefold: it is a great opportunity for English-language authors to get familiarized with leading research topics worldwide; it is a good opportunity for both Ph.D. students and academics to form a bridge between their native-language research community and the Englishspeaking research community; and it is a good chance for the young and/or unknown scholars from many non-English speaking countries to have a media outlet where they can showcase their latest findings in a relevant area of knowledge.

In the academic quest to keep up with the globalization of business (Aggarwal et al. 2008), international business and international management undoubtedly continue to retain its importance to both scholars and practitioners. As has been argued by other scholars before, it is also fairly certain that inquiries along the traditional business research areas and perspectives will endure (Griffith et al. 2008), but at the same time, there is also both a need and early evidence of the exploration of IM/IB/IS phenomena that are either new, gaining in importance, or challenging generality (Buckley and Lessard 2005) on the national, organizational or individual level (Peng 2004), including questions of cross-cultural competence (e.g., Johnson et al. 2006), migration and sustainability (Doz 2011), understanding the new rapidly growing economies in Asia (Fruin 2007), non-governmental organizations (Sullivan and Daniels 2008), emerging market multinationals (e.g., Luo and Tung 2007), bottom of the pyramid strategies (e.g., Prahalad and Hammond 2002), and issues of global inequality and ethics (Czinkota and 
Ronkainen 2009). In this context, the European Journal of International Management is strongly committed to help in the advancement of the field.

\section{References}

Aggarwal, R., Petrovic, J., Ryans, J. K., \& Zong, S. (2008). Outstanding international business research: nature of the best international business international dissertations. The Multinational Business Review, 16(1), 1-19.

Aharoni, Y. (1966). The Foreign Investment Decision Process. Boston: Division of Research, Graduate School of Business Administration Harvard University.

Anderson, E., \& Gatignon, H. (1986). Modes of foreign entry: a transaction cost analysis and propositions. Journal of International Business Studies, 17(3), 1-26.

Bartlett, C. A., \& Ghoshal, S. (1989). Management across borders. The transnational solution. Boston: Hutchinson Business Books.

Behrman, J. N. (2006). A career in the limbo of international business: policy, research and education. Journal of International Business Studies, 37, 432-444.

Brewster, C. (2007). A European perspective on HRM. European Journal of International Management, $1(3), 239-259$.

Brock, J. K. (2003). The 'power' of international business research. Journal of International Business Studies, 34, 90-99.

Buckley, P. J. (2002). Is the international business research agenda running out of steam? Journal of International Business Studies, 33(2), 365-373.

Buckley, P. J., \& Casson, M. (1976). The future of the multinational enterprise. London: MacMillan.

Buckley, P. J., \& Lessard, D. R. (2005). Regaining the edge for international business research. Journal of International Business Studies, 36, 595-599.

Cavusgil, T., \& Zou, S. (1994). Marketing strategy-performance relationship: an investigation of the empirical link in export market ventures. Journal of Marketing, 58, 1-21.

Cheng, J. L. C. (2007). Critical issues in international management research: an agenda for future advancement. European Journal of International Management, 1(1/2), 23-38.

Chetty, S., \& Blankenburg Holm, D. (2000). Internationalization of small to medium-sized manufacturing firms: a network approach. International Business Review, 9(1), 77-93.

Collinson, S., \& Rugman, A. M. (2010). Case selection biases in management research: the implications for international business studies. European Journal of International Management, 4(5), 441-463.

Cuervo-Cazurra, A., Maloney, M. M., \& Manrakhan, S. (2007). Causes of the difficulties in internationalization. Journal of International Business Studies, 38, 709-725.

Czinkota, M. R. (1994). A national export assistance policy for new and growing businesses. Journal of International Marketing, 2(1), 91-101.

Czinkota, M. R., \& Ronkainen, I. A. (2009). Trends and indication in international business: topics for future research. Management International Review, 49(2), 249-264.

Doz, Y. (2011). Qualitative research for international business. Journal of International Business Studies, 42, 582-590.

Dunning, J. H. (1977). Trade, location of economic activity and the multinational enterprise: a search for an eclectic approach. In B. Ohlin, P. O. Hesselborn, \& P. M. Wijkman (Eds.), The international allocation of economic activity. London: MacMillan.

Dunning, J. H. (2002). Perspectives on international business research: a professional autobiography fifty years researching and teaching international business. Journal of International Business Studies, 33(4), 817-835.

Dunning, J. H. (2007). A new Zeitgeist for international business activity and scholarship. European Journal of International Management, 1(4), 278-301.

Durmusoglu, S., Apfelthaler, G., Alvarez, R., Mughan, T., \& Nayir, D. Z. (2012). The role of export promotion service use on small and medium-sized enterprise goal achievement: a multidimensional view of export performance. Industrial Marketing Management, 41, 680-691.

Eden, L., \& Li, D. (2010-11). International business, international management, and International Strategy. International Studies of Management \& Organization, 40(4), 54-68. 
Fayerweather, J. (1960). Management of International Operations. New York/Toronto/London: MacGraw-Hill.

Fruin, W. M. (2007). Bringing the world (back) into international business. Journal of International Business Studies, 38, 252-256.

Ghemawat, P. (2003). Semiglobalization and international business strategy. Journal of International Business Studies, 34, 138-152.

Griffith, D. A., Cavusgil, S. T., \& Xu, S. (2008). Emerging themes in international business research. Journal of International Business Studies, 39, 1220-1235.

Hennart, J. F. (1991). The transaction costs theory of joint ventures: an empirical study of Japanese subsidiaries in the United States. Management Science, 37(4), 483-497.

Hirsch, S. (1967). Location of industry and international competitiveness. Oxford: Clarendon.

Hofstede, G. (1980). Culture's consequences. International differences in work-related values. Beverly Hills: Sage.

Hymer, S. H. (1960). The international operations of national firms: a study of direct investment. Cambridge: MIT.

Johanson, J., \& Vahlne, J.-E. (1977). The internationalization process of the firm: a model of knowledge development and increasing foreign market commitments. Journal of International Business Studies, 8(1), 23-32.

Johanson, J., \& Wiedersheim-Paul, F. (1975). The internationalization of the firm: four Swedish cases. Journal of Management Studies, 12(3), 305-322.

Johnson, J. P., Lenartowicz, T., \& Apud, S. (2006). Cross-cultural competence in international business: toward a definition and a model. Journal of International Business studies, 37, 525-543.

Keegan, W. J. (1967). Scanning the international business environment. A study of the Information Acquisition Process. Boston: Graduate School of Business Administration, Harvard University.

Kindleberger, C. P. (1969). American business abroad. 6 lectures on direct investment. New Haven: Yale University Press.

Knight, G. A., \& Cavusgil, T. S. (1996). The born global firm: a challenge to traditional internationalization theory. Advances in International Marketing, 8, 11-26.

Knight, G. A., \& Cavusgil, T. S. (2005). A taxonomy of born-global firm. Management International Review, 45(3), 15-35.

Kostova, T., Roth, K., \& Dacin, M. T. (2008). Institutional theory in the study of multinational corporations: a critique and new directions. Academy of Management Review, 33(4), 994-1006.

Leonidou, L. C., \& Katsikeas, C. S. (1996). The export development process: an integrative review of empirical models. Journal of International Business Studies, 27(3), 517-551.

Leung, K., Bhagat, R., Buchan, N., Erez, M., \& Gibson, C. (2005). Culture and international business: recent advances and their implications for future research. Journal of International Business Studies, 36(4), 357-378.

Luo, Y. D., \& Tung, R. L. (2007). International expansion of emerging market enterprises: a springboard perspective. Journal of International Business Studies, 38, 481-498.

Luthans, F., \& Doh, J. P. (2009). International management: culture, strategy, and behavior (7th ed.). New York: McGraw-Hill Irwin.

Madsen, T. K., \& Servais, P. (1997). The internationalization of born globals: an evolutionary process. International Business Review, 6, 61-583.

McDougall, P. P. (1989). International versus domestic entrepreneurship: new venture strategic behavior and industry structure. Journal of Business Venturing, 4(6), 387-400.

Moen, O. (2002). The born globals. A New Generation of Small European Exporters, International Marketing Review, 19(2-3), 156-175.

Moen, O., \& Servais, P. (2002). Born global or gradual global? Examining the Export Behavior of Small and Medium-Sized Enterprises, Journal of International Marketing, 10(3), 49-72.

OECD (Organization for Economic Cooperation and Development). (2005). Employment Outlook, Paris.

Oesterle, M. J., \& Laudien, S. (2007). The future of international business research and the relevance gap: a German perspective. European Journal of International Management, 1(1/2), 39-55.

Oviatt, B. M., \& McDougall, P. P. (1994). Toward a theory of INVs. Journal of International Business Studies, 25(1), 45-64.

Oviatt, B. M., \& McDougall, P. P. (1995). Global start-ups: entrepreneurs on a worldwide stage. Academy of Management Executive, 9(2), 30-43.

Oviatt, B. M., \& McDougall, P. P. (2005). Defining international entrepreneurship and modelling the speed of internationalization. Entrepreneurship Theory and Practice, 29(5), 537-553. 
Pauleen, D. J., Rooney, D., \& Holden, N. J. (2010). Practical wisdom and the development of crosscultural knowledge management: a global leadership perspective. European Journal of International Management, 4(4), 382-395.

Peng, M. W. (2001). The resource-based view and international business. Journal of Management, 27, $803-829$.

Peng, M. W. (2004). Identifying the big question in international business research. Journal of International Business Studies, 35, 99-108.

Peng, M. W., Wang, D. Y. L., \& Jiang, Y. (2008). An institution-based view of international business strategy: a focus on emerging economies. Journal of International Business Studies, 39, 920-936.

Penrose, E. T. (1956). Foreign investment and the growth of the firm. Economic Journal, 66, 230-235.

Prahalad, C. K., \& Hammond, A. (2002). Serving the world's poor, profitably. Harvard Business Review, $80(9), 48-57$.

Rennie, M. (1993). Global competitiveness: born global. McKinsey quarterly, 4, 45-52.

Sagiv, L., \& Schwartz, S. H. (2007). Cultural values in organisations: insights for Europe. European Journal of International Management, 1(3), 176-190.

Shenkar, O. (2004). One more time: international business in a global economy. Journal of International Business Studies, 35, 161-171.

Sullivan, D. P., \& Daniels, J. D. (2005). Defining international business through its research. In P. J. Buckley (Ed.), What is international business, Houndmills, Basingstoke, Hampshire, and New York (pp. 68-84). NY: Palgrave MacMillan.

Sullivan, D. P., \& Daniels, J. D. (2008). Innovation in international business research: a call for multiple paradigms. Journal of International Business Studies, 39, 1081-1090.

Vernon, R. (1966). International investment and international trade in the product cycle. The quarterly journal of economics, 80(2), 190-207.

Wilkins, M. (1970). The emergence of multinational enterprise: American business abroad from the colonial era to 1914. Cambridge: Harvard University Press.

Wilkins, M. (1974). The maturing of multinational enterprise: American business abroad from 1914 to 1970. Cambridge: Harvard University Press.

Zahra, S. A., Ireland, R. D., \& Hitt, M. A. (2000). International expansion by new venture firms: international diversity, mode of market entry, technological learning, and performance. Academy of Management Journal, 43(5), 925-950.

Zou, S., Taylor, C. R., \& Osland, G. E. (1998). The EXPERF Scale: a cross-national generalized export performance measure. Journal of International Marketing, 6(3), 37-58. 